\title{
PENGEARUH PERSEPSI GURU TENTANG KECERDASAN EMOSIONAL KEPALA SEKOLAH TERHADAP KINERJA GURU DI SMK NEGERI KOTA MEDAN
}

\author{
Ngatmini \\ mini_ngatmini@yahoo.co.id
}

\begin{abstract}
Abstrak
Persepsi Guru tentang Kecerdasan Emosional Kepala Sekolah Terhadap Kinerja Guru. Populasi penelitian adalah guru-guru SMK Negeri Kota Medan sebanyak 328 orang. Sampel penelitian sejumlah 76 orang yang diambil secara Stratified Proportional Random Sampling. Metode penelitian adalah kuantitatif jenis deskriptif studi korelasional. Instrumen pengumpulan untuk semua variabel menggunakan angket berskala Likert.

Untuk mengumpulkan data digunakan angket. Untuk persyaratan analisis dilakukan uji validitas dan uji reliabilitas. Untuk menguji hipotesis yang diajukan dalam penelitian ini, digunakan teknik korelasi sederhana. Berdasarkan pengujian hipotesis dapat disimpulkan bahwa terdapat hubungan yang positif dan berarti antara : persepsi guru tentang kecerdasan emosional kepala sekolah terhadap kinerja guru, korelasi $r_{\text {hitung }}>r_{\text {tabel }}(0,397>0,227)$ dan $t_{\text {hitung }}>t_{\text {tabel }}(3,720>1,67)$, maka dapat dikatakan bahwa terdapat hubungan yang positif dan berarti antara persepsi guru tentang kecerdasan emosional kepala sekolah terhadap kinerja guru dapat diterima dan diuji kebenarannya.

Kepala sekolah disarankan untuk memperbaiki kecerdasan emosional untuk mengambil kebijakan, sehingga semua kebijakan dapat mengurangi masalah yang muncul dalam manajemen sekolah.
\end{abstract}

Kata kunci : persepsi, kecerdasan emosional, kinerja

\section{A. Latar Belakang Masalah}

Pendidikan Nasional berfungsi

mengembangkan kemampuan dan

membentuk watak serta peradaban bangsa

yang bermartabat dalam rangka

mencerdaskan kehidupan bangsa,

bertujuan untuk berkembangnya potensi

peserta didik agar menjadi manusia yang

beriman dan bertakwa kepada Tuhan Yang

Maha Esa, berakhlak mulia, sehat,

berilmu, cakap, kreatif, mandiri, dan menjadi warga negara yang demokratis, serta bertanggung jawab (UU No. 20, 2003 pasal 3).

Berdasarkan tujuan pendidikan nasional ini sangat jelas peranan guru sangat esensial dan vital. Sebagai salah satu komponen dalam proses belajar mengajar (PBM), guru memiliki posisi yang sangat menentukan keberhasilan pembelajaran dalam merancang, mengelola, melaksanakan dan 
mengevaluasi pembelajaran. Guru sentral dalam meningkatkan proses belajar mengajar. Di tangan para guru terletak kemungkinan berhasil atau tidaknya pencapaian tujuan belajar mengajar di sekolah, serta di tangan mereka pula bergantungnya masa depan karir peserta didik yang menjadi tumpuan para orang tua. Maka diharapkan melalui proses ini peserta didik mempunyai sejumlah kepandaian dan kecakapan tentang sesuatu yang dapat membentuk kematangan pribadinya.

Guru sebagai tenaga pendidik yang mempunyai peran sebagai faktor penentu keberhasilan tujuan suatu organisasi selain tenaga kependidikan lainnya, karena guru yang langsung bersinggungan dengan peserta didik untuk memberikan bimbingan yang muaranya akan menghasilkan tamatan yang diharapkan. Untuk itu kinerja guru harus selalu ditingkatkan. Dalam dunia pendidikan kinerja guru atau prestasi kerja merupakan hasil yang dicapai guru dalam memiliki kedudukan sebagai figur melaksanakan tugas-tugas yang didasarkan atas kecakapan, pengalaman dan kesungguhan serta penggunaan waktu di dalam proses belajar mengajar di sekolah.

\section{Sekolah Menengah Kejuruan} (SMK) merupakan salah satu bentuk satuan pendidikan yang mempunyai tujuan mempersiapkan peserta didik agar menjadi manusia produktif, mampu bekerja mandiri, mengisi lowongan pekerjaan yang ada. Berdasarkan Kurikulum tingkat satuan pendidikan tahun 2004, pada jenjang pendidikan SMK dibagi atas 3 kelompok mata diklat yaitu : (1) mata diklat normatif, (2) mata diklat adaptif, dan (3) mata diklat produktif. Pelaksanaan pembelajaran di SMK lebih banyak menekankan pada pembelajaran praktik, sehingga keberadan fasilitas yang berupa sarana prasarana praktik sangat diperlukan. Upaya yang telah dilakukan pemerintah berupa penataan kembali kebijakan pendidikan kejuruan dengan disertai pembangunan sarana dan prasarana praktik 
atau laboratorium. Sarana yang berupa gedung dan prasarana yang berupa alatalat praktik merupakan identitas dari suatu Sekolah Menengah Kejuruan. Kompetensi guru SMK terutama guru mata diklat produktif dalam memanfaatkan sarana dan prasarana praktik sangat diperlukan. Kemampuan guru dalam memanfaatkan sarana dan prasarana praktik yang baik akan memperlancar kegiatan pembelajaran praktik, sehingga kompetensi lulusan SMK akan dapat ditingkatkan.

Indikasi kinerja guru yang rendah masih ditemukan bagi guru-guru mata diklat produktif di SMK Negeri Kota Medan. Kenyataan ini tampak dari persiapan guru dalam pembelajaran seperti Program tahunan, Program semester, Silabus dan Rencana Pelaksanaan Pembelajaran (RPP) belum tertata dengan baik, keinginan yang rendah dari guru untuk melaksanakan pembelajaran yang variatif demikian juga dalam hal pemanfaatan dari media dan sumber belajar . Apabila dilihat dari perangkat pembelajaran sudah $90 \%$ lengkap. Namun pada kenyataannya, kelengkapan perangkat pembelajaran tersebut hampir $70 \%$ bukan hasil karya guru masingmasing, melainkan hasil copy dari rekan guru lainnya. Idealnya RPP yang ada di sekolah bervariasi pengembangannya dan mempunyai karakteristik tertentu untuk setiap guru, namun kenyataannya semua RPP dan semua perangkat pembelajaran sama kalimat maupun isinya antara sesama guru mata diklat.

Hasil observasi di lapangan yang dilakukan terhadap 3 SMK Negeri di Kota yang menunjukkan kinerja yang belum optimal yaitu dilihat dari jumlah guru mata diklat produktif yang lulus fortofolio dan yang mengikuti PLPG dalam Sertifikasi Guru sampai bulan Desember 2011

Hal ini menimbulkan pertanyaan, apakah memang rendah kinerja guru di SMK Negeri Kota Medan, padahal diharapkan guru-guru di SMK Negeri Kota Medan memiliki kinerja yang tinggi 
agar siswa-siswi lulusan dapat memperoleh nilai yang sesuai dengan kriteria kelulusan yang maksimal dan kompeten dalam bidang keahliannya sehingga diharapkan lulusan dapat bersaing dan diterima bekerja di dunia usaha dan industri, membuka usaha serta SMK menunjukkan bahwa hampir $60 \%$ guru yang telah mendapat tunjangan sertifikasi dalam kegiatan belajar mengajar saat awal menerima tunjangan mengalami peningkatan kinerja. Guruguru mengajar dengan disiplin, tepat waktu, melengkapi perangkat pembelajaran dengan berusaha belajar serta mencari inovasi baru. Namun setelah satu tahun berjalan, muncul kembali budaya tidak tepat waktu dan enggan berusaha membuat perangkat pembelajaran sendiri serta kurang peduli terhadap inovasi dalam mengajar. Kejenuhan terlihat pada diri guru-guru dalam melaksanakan tugas seperti kurangnya kreatifitas dan inovasi dalam proses pembelajaran. Selain itu faktor usia melanjutkan pendidikan di sekolah. Hasil pengamatan dan wawancara dengan beberapa orang guru dilapangan ditemukan bahwa guru-guru yang telah lulus sertifikasi dan mendapat tunjangan belum menunjukkan kinerja yang optimal. Berdasarkan hasil observasi terhadap 3 rata-rata di atas 45 tahun dan merasa sudah mapan dalam mengajar sehingga tidak mau berusaha mengadakan inovasi untuk mencapai kinerja yang optimal.

Sekolah sebagai lembaga pendidikan memerlukan seorang pemimpin yang memiliki kecerdasan emosional yang tinggi dan memiliki wawasan yang lebih besar tentang jenis daya tarik rasional atau emosional yang paling mungkin menjadi efektif dalam sebuah situasi. Keberhasilan kepala sekolah dalam kepemimpinannya tergantung besarnya tanggung jawab pada kejadian sehari-hari yang terjadi di sekolah. Namun pada kenyataannya, masih ada dibeberapa sekolah yang memiliki kepala sekolah dalam kepemimpinannya 
bekerja kurang optimal. Kondisi yang sering terjadi misalnya dalam pengambilan keputusan, seorang kepala sekolah yang mengandalkan kepemimpinan otoriter. Seharusnya ada bagian tertentu dari sebuah keputusan yang harus dimusyawarahkan dengan wakil kepala sekolah atau guru.. Hasil pengamatan dan wawancara dengan guru sebenarnya berpotensi dan mempunyai loyalitas yang tinggi. Namun saat ini sedang mengalami masalah keluarga dan di saat kondisi seperti inilah membutuhkan perhatian dari atasan untuk dapat mengurangi permasalahan yang dialaminya. Pemberian tugas tambahan diharapkan sekali oleh guru tersebut untuk mengurangi beban ekonomi keluarga. Karena dengan tugas tambahan tersebut diharapkan ia akan mendapat honor tambahan. Namun karena kepala sekolah tidak mengelola emosi terhadap informasi yang ada, menyebabkan hubungan kerja kurang harmonis dengan guru. Dalam menanggapi permasalahan di atas, seharusnya kepala sekolah dapat melaksanakan kepemimpinan secara efektif. Hal ini sering menjadi pemicu ketidakpuasan guru terhadap kebijakan yang dibuat oleh kepala sekolah dan mengakibatkan kinerja guru kurang optimal.

Peningkatan kinerja guru yang optimal dalam organisasi sekolah pada langkah awalnya pelaksanaannya diperlukan sebuah komitmen guna memperolah hasil kerja yang optimal dalam melaksanakan tugas sebagai seorang guru. Dari permasalahan yang dialami guru menunjukkan masih rendahnya tanggung jawab guru dan dianggap guru rendah komitmen dalam mengajar dimana akhirnya mengakibatkan rendahnya komitmen terhadap sekolah.

$$
\text { Dengan demikian dapat }
$$
disimpulkan bahwa dalam melaksanakan tugas dan tanggungjawabnya, setiap guru dituntut mempunyai kinerja yang optimal sesuai dengan kompetensi dan profesionalitas di bidangnya atau setidaknya mampu menguasai dan dapat 
melaksanakan. Disadari bahwa dalam organisasi atau lembaga diperlukan suatu strategi yang baik untuk dapat mengelola manusia sebagai sumber daya yang memiliki komitmen dan kinerja yang tinggi. Komitmen menunjukkan bahwa secara internal menyetujui dan membuat suatu upaya yang besar untuk melaksanakannya. Hal ini menunjukkan bahwa komitmen dalam bertindak sesuai dengan tujuan pribadi dan tujuan organisasi serta untuk memperlancar tercapainya tujuan sekaligus meningkatkan kinerja. Keyakinan inilah yang dikatakan sebagai kesetiaan atau komitmen. Jika seorang guru sudah berkomitmen dalam melaksanakan tugasnya maka diharapkan kinerjanya akan meningkat, sehingga tercapai tujuan yang optimal dalam mengasilkan peserta didik yang berkualitas.

Jika guru mempunyai komitmen yang tinggi, maka akan menunjukkan rasa pengabdian dan tanggung jawab, rasa tulus ikhlas, konsentrasi dalam bekerja dan tanpa keluh kesah membantu siswa belajar. Guru yang berkomitmen akan terus berupaya mencari cara-cara baru dalam peningkatan kualitas pekerjaan. Sehingga komitmen guru mempunyai hubungan dengan kinerja guru.

Permasalahan yang dibahas adalah hubungan antara persepsi guru tentang kecerdasan emosional kepala sekolah dengan kinerja guru di SMK Negeri Kota Medan.

Kirkpatrik dan Nixon dalam Sagala (2006:179) mengartikan kinerja sebagai ukuran kesuksesan dalam pencapaian tujuan yang telah ditetapkan (direncanakan) sebelumnya.

$$
\text { Selanjutnya Fatah (2000:19) }
$$

mengatakan bahwa prestasi kerja atau kinerja adalah sebagai ungkapan kemampuan yang didasari oleh intelegensi/pengetahuan, sikap, keterampilan dan motivasi dalam menghasilkan sesuatu.

$$
\text { Maka kinerja merupakan }
$$

penampilan hasil karya seseorang dalam 
bentuk kualitas ataupun kuantitas dalam suatu organisasi. Kinerja dapat merupakan penampilan individu maupun kelompok kerja pegawai.

Thoha

(2008:141-142),

mengungkapkan bahwa persepsi pada hakikatnya adalah proses kognitif yang dialami oleh setiap orang di dalam memahami informasi tentang

Persepsi itu bersifat subjektif maka setiap individu dapat memiliki pandangan yang berbeda tentang satu objek yang sama, tentang situasi atau pesan tertentu menjadi landasan berdasarkan apa ia berperilaku.

Robbins dan Judge (2008:335) mengatakan bahwa keceradasan emosional adalah kemampuan seseorang untuk mendeteksi serta mengelola petunjuk-petunjuk dan informasi emosional. Orang- orang yang mengenal emosi-emosi mereka sendiri dan mampu dengan baik membaca orang lain dapat menjadi lebih efektif dalam pekerjaan mereka. Menurut Robbins dan Judge lingkungannya, baik lewat penglihatan, pendengaran, penghayatan, perasaan, dan penciuman. Gibson, Ivencevich, dan Donnely (1985:103) mengatakan bahwa persepsi merupakan proses kognitif yang dipergunakan oleh seseorang untuk menafsirkan dan memahami dunia sekitarnya.

(2008 : 335) inti dari kecerdasan emosional ada 5 yaitu :

(1) kesadaran diri ; sadar atas apa yang dirasakan sendiri, (2) manajemen diri; kemampuan mengelola emosi dan dorongandorongan dalam diri sendiri, (3) motivasi diri ; kemampuan bertahan dalam menghadapi kemunduran dan kegagalan, (4) empati ; kemampuan merasakan apa yang dirasakan orang lain, (5) keterampilan sosial ; kemampuan menangani emosi-emosi orang lain.

Golemen (1997:45) mengatakan bahwa kecerdasan emosional adalah kemampuan untuk memotivasi diri sendiri dan bertahan menghadapi frustasi, mengendalikan dorongan hati dan tidak melebig-lebihkan kesenangan, mengatur suasana hati dan menjaga agar beban stres 
tidak melumpuhkan kemampuan berfikir, berempati dan berdoa.

Seorang pemimpin yang memiliki kecerdasan emosional yang tinggi akan memiliki wawasan yang lebih besar tentang jenis daya tarik rasional atau emosional yang paling mungkin menjadi efektif dalam sebuah situasi tertentu. Keterampilan mengenali perasaan seseorang dengan menjalin hubungan dengan cepat dan lancar, memperhatikan

\section{B. HASIL PENELITIAN}

Dalam penelitian ini data yang diambil ada tiga jenis yaitu: persepsi guru tentang kecerdasan emosional kepala sekolah terhadap kinerja guru.

Data yang dideskripsikan pada penelitian ini meliputi data skor persepsi nasib, memberi hiburan adalah melukiskan suatu bakat keterampilan emosional. Keterampilan-keterampilan seperti itu merupakan cikal bakal bakat yang akan matang seiring dengan waktu. Seseorang yang mampu menyesuaikan diri dengan suasana hati individu lain atau dapat berempati dengan orang lain menunjukkan bahwa tingkat pengaturan emosionalnya tinggi, hal ini akan memudahkan penyesuaian diri dalam lingkungannya.

guru tentang kecerdasan emosional kepala sekolah terhadap kinerja guru sekolah yang diambil dari 76 orang sampel guru di SMK Negeri Kota Medan. Secara ringkas data skor hasil penelitian dapat dilihat pada Tabel berikut :

Tabel Rangkuman Hasil Skor Variabel Penelitian

\begin{tabular}{|l|c|c|}
\hline \multicolumn{1}{|c|}{ Statistik } & Kinerja guru & $\begin{array}{c}\text { Persepsi guru tentang } \\
\text { kecerdasan emosional kepala } \\
\text { sekolah }\end{array}$ \\
\hline Nilai Tertinggi & 123 & 130 \\
\hline Nilai Terendah & 78 & 80 \\
\hline Mean & 99,961 & 105,145 \\
\hline
\end{tabular}




\begin{tabular}{|l|c|c|}
\hline \multicolumn{1}{|c|}{ Statistik } & Kinerja guru & $\begin{array}{c}\text { Persepsi guru tentang } \\
\text { kecerdasan emosional kepala } \\
\text { sekolah }\end{array}$ \\
\hline Modus & 101,5 & 105,5 \\
\hline Median & 100,25 & 105,633 \\
\hline Standar Deviasi & 12,558 & 13,002 \\
\hline
\end{tabular}

Dari uji hipotesis persepsi guru tentang kecerdasan emosional kepala sekolah terhadap kinerja guru, didapat

\section{Pembahasan}

\section{Persepsi guru tentang kecerdasan} emosional kepala sekolah terhadap kinerja guru.

Berdasarkan data skor Persepsi guru tentang kecerdasan emosional kepala sekolah yang terkumpul, menyebar dari skor 80 sampai 135, dengan Modus (Mo) $=105,5 ;$ Median $(\mathrm{Me})=105,633 ;$ Mean $(M)=105,145 ;$ dan Standard Deviasi (SD) $=13,002$. Data skor kinerja guru yang terkumpul, menyebar dari skor 78 sampai 126, dengan Modus $(\mathrm{Mo})=101,5 ;$ Median $(\mathrm{Me})=100,25 ;$ Mean $(\mathrm{M})=99,961 ;$ dan Standard Deviasi $(\mathrm{SD})=12,558$. korelasi $r_{\text {hitung }}>r_{\text {tabel }}(0,397>0,227)$ dan $t_{\text {hitung }}>t_{\text {tabel }}(3,720>1,67)$.

Ditemukan bahwa kinerja guru di SMK Negeri Kota Medan termasuk dalam kategori sedang. Untuk itu perlu dilakukan upaya dalam meningkatkan kinerja guru di SMK Negeri Kota Medan. Dari 76 orang responden yang diteliti, ditemukan 9 responden $(11,843 \%)$ kategori rendah, 54 responden $(71,105 \%)$ kategori sedang, dan 13 responden $(17,105 \%)$ kategori tinggi. Informasi ini menunjukkan bahwa masih harus terus ditingkatkan kinerja guru di SMK Negeri Kota Medan. Kinerja guru dalam mengajar, harus terus ditingkatkan mengingat sangat diperlukan kompetensi guru dalam mengajar.

Persepsi Guru Tentang Kecerdasan Emosional Kepala Sekolah -109 Terhadap Kinerja Guru di SMK Negeri Kota Medan 
Guru diharuskan untuk memiliki ilmu pengetahuan dan kemampuan dalam memberikan ilmu pengetahuan kepada siswa. Semakin baik kompetensi guru dalam mengajar, akan memberikan hasil yang lebih baik bagi pengetahuan/ keterampilan siswa. Beberapa faktor yang diduga dapat memberikan peningkatan kinerja guru di SMK Negeri Kota Medan di antaranya persepsi guru tentang kecerdasan emosional kepala sekolah dan komitmen guru di SMK Negeri Kota Medan. Disisi lain yang untuk meningkatkan dan mengembangkan kemampuan yang menggambarkan peningkatan kinerja guru yaitu, setiap guru perlu mempunyai persepsi positif terhadap pemimpin sekolah yaitu kepala sekolah tentang kecerdasan emosional. Kecerdasan emosional yang dimiliki dalam diri seseorang menyangkut perilaku sebagai pemimpin dimana dapat menentukan tinggi atau rendahnya kinerja guru. Kepala sekolah dituntut untuk memiliki kecerdasan dalam membangun hubungan dengan guru di sekolah. Bentuk konkrit dari hubungan pribadi misalnya dengan pemberian kritik atas kinerja seorang guru yang kurang baik selama mengajar.

Persepsi guru tentang kecerdasan emosional kepala sekolah terhadap kinerja guru di SMK Negeri Kota Medan tergolong sedang. Dengan ini menunjukkan perlu terus ditingkatkan kecerdasan emosional kepala sekolah dalam pengelolaan manajemen, pembinaan hubungan, pengelolaan emosi, empati di SMK Negeri Kota Medan. Dalam menjalankan pengelolaan pembelajaran di sekolah, kepala sekolah perlu memiliki kemampuan dalam memecahkan setiap permasalahan yang dihadapi guru. Keberhasilan kepala sekolah dalam kepemimpinannya tergantung besarnya tanggung jawab pada kejadian sehari-hari yang terjadi di sekolah. Masih banyak guru yang belum dapat melaksanakan tugasnya sesuai dengan ketentuan yang telah 
ditetapkan pemerintah. Dalam upaya

mencapai tujuan tersebut, diperlukan

kecerdasan emosioanal kepala sekolah

Orang- orang yang mengenal emosi-emosi

mereka sendiri dan mampu dengan baik

membaca orang lain dapat menjadi lebih

efektif dalam pekerjaan mereka.

kinerja para guru dengan

menunjukkan rasa bersahabat, dekat, dan

penuh pertimbangan, baik sebagai individu

maupun sebagai kelompok. Perilaku

instrumental merupakan tugas-tugas yang

diorientasikan dan secara langsung

diklarifikasi dalam peranan dan tugas-

\section{SIMPULAN}

Persepsi guru tentang kecerdasan emosional kepala sekolah terhadap kinerja guru di SMK Negeri Kota Medan tergolong sedang. Sehingga perlu perlu terus ditingkatkan secara optimal kecerdasan emosional kepala sekolah dalam pengelolaan manajemen, pembinaan hubungan, pengelolaan emosi, empati di SMK Negeri Kota Medan. Dalam
Kepemimpinan berkaitan dengan peningkatan kesempatan untuk mengadakan pertemuan secara efektif dengan para bawahan (dalam hal ini guru) dalam situasi yang kondusif. Perilaku seorang kepala sekolah harus dapat mendorong

tugas para pegawai/ bawahan, sebagai individu dan sebagai kelompok. Perilaku pemimpin yang positif dapat mendorong kelompok dalam mengarahkan dan memotivasi individu untuk bekerja sama dalam kelompok dalam rangka mewujudkan tujuan perguruan tinggi.

menjalankan pengelolaan pembelajaran di sekolah, kepala sekolah perlu memiliki kemampuan dalam memecahkan setiap permasalahan yang dihadapi guru. Keberhasilan kepala sekolah dalam kepemimpinannya tergantung besarnya tanggung jawab pada kejadian sehari-hari yang terjadi di sekolah. Masih banyak guru yang belum dapat melaksanakan tugasnya sesuai dengan ketentuan yang telah 
ditetapkan pemerintah. Dalam upaya

mencapai tujuan tersebut, diperlukan

kecerdasan emosioanal kepala sekolah

Artinya semakin baik persepsi guru

\section{DAFTAR PUSTAKA}

Arikunto, Suharsimi. 2010. Prosedur Penelitian Suatu Pendekatan Praktek. Jakarta: Rineka Cipta.

Gibson, James L, John M. Ivancevich, dan James H. Donnelly, Jr. 1995. Organization: Perilaku, Struktur, Proses, terjemahan Nunuk Adiarni. Jakarta: Bina Aksara.

Goleman, Daniel. 2000. Emotional Intelligence. Penerjemah T. Hermaya. Jakarta: Gramedia Pustaka Utama.

Fatah, Nanang. 2000. Manajemen Berbasis Sekolah Strategi Pemberdayaan Sekolah Dalam Rangka Peningkatan Mutu dan Kemandirian Sekolah. Bandung: Andira.

Robbins, Stephen.P dan Timothy A.Judge. 2008. Perilaku Organisasi. Edisi Kedua belas, Alih Bahasa: Diana Angelica. Indonesia: Salemba.

Robbins, Stephen,P dan Coulter. 2007. Perilaku Organisasi. Edisi Kesepuluh, Alih Bahasa: Benyamin Molan. Indonesia: Mancana Jaya Cemerlang. tentang kecerdasan emosional kepala sekolah maka semakin baik juga kinerja guru di SMK Negeri Kota Medan.

Sagala, H. Syaiful. 2007. Administrasi Pendidikan Kontemporer. Bandung: Alfabeta.

Sudjana. 2005. Metoda Statistika. Bandung: Tarsito.

Sugiyono. 2010. Statitiska Untuk Penelitian.Bandung: Alfabeta.

Thoha, Miftah. 2008. Perilaku Organisasi Konsep Dasar dan Aplikasinya. Jakarta: Raja Grafindo Persada.

Weisigner, H. 2006. Emotional Intellegence at Work. Jakarta: Bhuana Ilmu Populer.

Wijaya, Cece, dan A. Tabrani Rusyan. 1991. Kemampuan Dasar Guru dalam Proses Belajar Mengajar. Bandung: Remaja Rosdakarya.

Yulk, Gary. 2007. Kepemimpinan Dalam Organisasi, Edisi Kesembilan, terjemahan Budi Supriyanto. Jakarta: Indeks.

2005.

Kepemimpinan Dalam Organisasi, Edisi Ketujuh, terjemahan Budi Supriyanto. Jakarta: Indeks. 